\title{
DFT Study of Se-Doped Nanocones as Highly Efficient Hydrogen Storage Carrier
}

\author{
Ahlam Abdulmonem Ahmed EL-Barbary ${ }^{1,2}$ (), Mohammed Ahmed Alkhateeb ${ }^{3 *}$ (1) \\ ${ }^{1}$ Physics Department, Faculty of Education, Ain-Shams University, Cairo, Egypt \\ ${ }^{2}$ Physics Department, Faculty of Science, Jazan University, Jazan, Saudi Arabia \\ ${ }^{3}$ Physics Department, Faculty of Education and Science, Taiz University, Taiz, Yemen \\ Email: ^m_alkhateeb77@yahoo.com
}

How to cite this paper: EL-Barbary, A.A.A. and Alkhateeb, M.A. (2021) DFT Study of Se-Doped Nanocones as Highly Efficient Hydrogen Storage Carrier. Graphene, 10, 49-60.

https://doi.org/10.4236/graphene.2021.104004

Received: September 19, 2021

Accepted: October 15, 2021

Published: October 18, 2021

Copyright (c) 2021 by author(s) and Scientific Research Publishing Inc. This work is licensed under the Creative Commons Attribution International License (CC BY 4.0).

http://creativecommons.org/licenses/by/4.0/

\section{(c) (i) Open Access}

\begin{abstract}
We have investigated the high capacity of Selenium atom (Se) doped nanocones surfaces as hydrogen storage systems. Hydrogen is a clean source of energy and it is derived from diverse domestic and sustainable resources. Hence, it can use as a viable alternative to fossil fuels. Therefore, the hydrogen storage on pure and doped Se-CNCs, BNNCs and SiCNCs was studied by density functional theory (DFT) method. The obtained results show that the lowest adsorption energy and the highest surface reactivity are $-31.03 \mathrm{eV}$ and 39.73 Debye for $\mathrm{Se}_{-} \mathrm{Si}_{34} \mathrm{C}_{41} \mathrm{H}_{9}-\mathrm{M} 1$ with disclination angle $300^{\circ}$, respectively. Therefore, one can conclude that the doped Se-SiCNCs are good candidate for hydrogen storage. This finding was also confirmed by using the molecular orbital analysis. It is found that doping NCs with Se atom results in increasing the electron density around the Se atom and leading to increase the hydrogen storage capacity. The new understanding of highly efficient hydrogen storage for doped Se-SiCNCs, will be useful for the future synthesis of nancones with high performance for $\mathrm{H}_{2}$ energy storage.
\end{abstract}

\section{Keywords}

CNCs, BNNCs, SiCNCs, DFT, Hydrogen Adsorption, Hydrogen Storage, Se-NCs

\section{Introduction}

With the consumption of fossil fuels and the increasing environmental pollution, people urgently need to find a new type of clean, sustainable and environmentally friendly energy to replace the traditional energy carriers [1]-[10]. The 
energy derived from renewable energy, and alternative energy sources receive considerable research attention [11]-[21]. Hydrogen is an ideal gas for energy source [22]-[31]. As reported by the United States Department of Energy (DOE), the storage of hydrogen is still the most difficult of these technological challenges. The department of Energy was determined the required hydrogen storage density of $9 \mathrm{wt} \%$ to replace the petroleum-fueled vehicles by fuel-cells vehicles and in practical application a high wt\% is required to make hydrogen available alternative to fossil fuel. The $w t \%$ is defined as the ratio of the mass of the stored hydrogen to the mass of the storage system [32] [33] [34].

$\mathrm{H}_{2}$ can be obtained by chemical reaction and stored as liquid-hydrogen storage, solid-state conformable storage, and compressed fuel storage which they require very high-pressures, heavy machinery, and offers low storage efficiency. However, nanomaterials are believed to be suitable for hydrogen storage applications due to their inexpensive, lightweight, chemically stable, in addition to their desirable hydrogen-adsorption and desorption energies.

Nanocones, NCs, characterized by their high chemical reactivity due to nanowindows opening at either tips or sidewalls of NCs [35] [36] [37] [38] [39]. Therefore, in this study, we have chosen three types of nanocones (NCs) as carbon nanocones (CNCs), boron nitride nanocones (BNNCs) and silicon carbide nanocones (SiCNCs) with two disclination angles $60^{\circ}$ and $300^{\circ}$. Each configuration of nanocones is doped by Selenium (Se) atom, then it is monohydrogenated.

Selenium (Se), is a chemical element with atomic number 34. It is a chalcogenide element with unique photoelectric property and photoconductivity. In addition, it can use as an excellent semiconductor component for many applications such as solar cells, electrochemical sensors and electrocatalysis [40]-[47]. Due to the unique physical, chemical and biochemical properties of selenium, it participates in numerous important life processes and it is attracted numerous attentions in biosensing, catalysis, diagnosis as well as treatment of diseases. Therefore, recent studies on Selenium-based nanomaterials are mainly interested on quantum dots or selenium nanoparticles while other applications as hydrogen storage and other novel selenium-based nanomaterials as Se-nanocones are less studied.

Hence, in this study, the adsorption energy, the energy gaps (Eg), the highest occupied molecular orbitals (HOMO) and the lowest unoccupied molecular orbitals (LUMO) and the surface reactivity of pure and Se-doped CNCs, BNNCs and $\mathrm{SiCNCs}$ with disclination angles $60^{\circ}$ and $300^{\circ}$ are investigated.

\section{Computational Details}

The monohydrogenated of pure and Se-doped nanocones was performed with full geometry optimization using the Density Functional Theory (DFT). The Becke's three parameter hybrid functional with LYP correlation functional (B3LYP) [48] [49] and standard basis set as implemented in the Gaussian $03 \mathrm{~W}$ program [50] are applied. All calculations carried out using Gauss View 4 mole- 
cular visualization program Package [51]. The samples of study are pure NCs, Se-doped NCs, monohydrogenated pure NCs and monohydrogenated of Se-doped NCs. We applied three types of NCs, CNCs, BNNCs and SiCNCs with disclination angles $60^{\circ}$ and $300^{\circ}$. For BNNCs with disclination angles $60^{\circ}$ and $300^{\circ}$, there are two models (M1 and M2), resulting from the connected atoms edges either nitrogen atoms (named M1) or boron atoms (named M2), see Figure 1(a) and Figure 1(b) and Figure 2(a) and Figure 2(b), respectively. Similarly, for SiCNCs, there are two models (M1 and M2), where the connected atoms edges are either silicon atoms (named M1) or carbon atoms (named M2), see Figure 1(c) and Figure 1(d) and Figure 2(c) and Figure 2(d), respectively. The fully optimized configurations of three types of nanocones with disclination angles $60^{\circ}$ and $300^{\circ}$ are shown in Figure 1 and Figure 2.

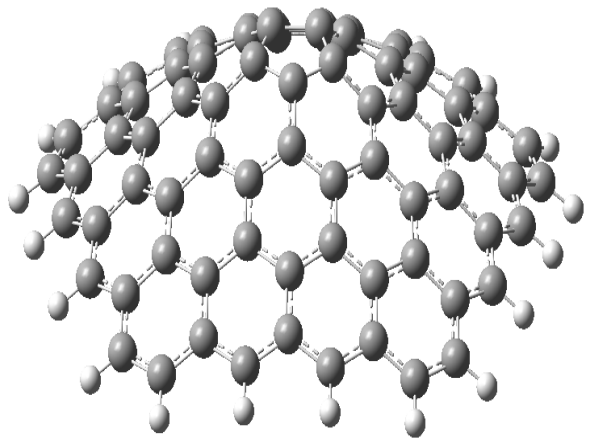

(a)

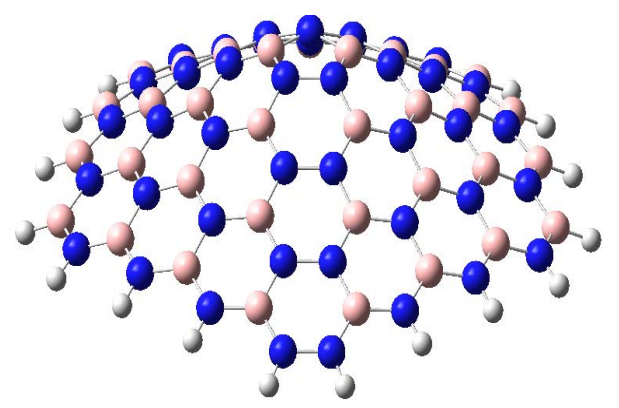

(b)

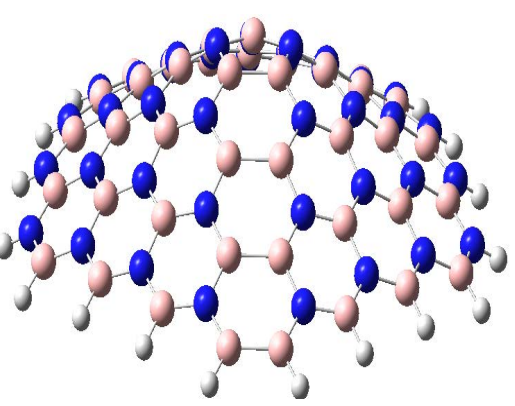

(c)

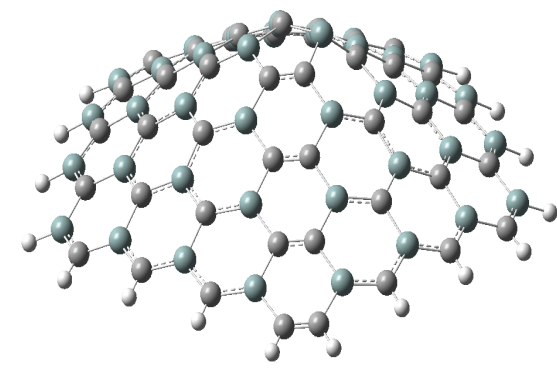

(d)

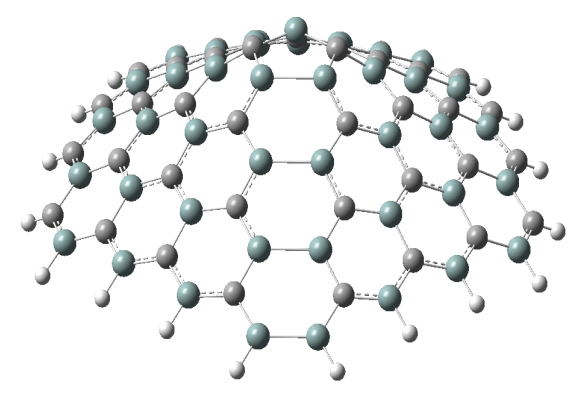

(e)

Figure 1. The fully optimized structures of pure nanocones with disclination angle $60^{\circ}$ (a) $\mathrm{C}_{80} \mathrm{H}_{20}$, (b) $\mathrm{B}_{38} \mathrm{~N}_{42} \mathrm{H}_{20}-\mathrm{M} 1$, (c) $\mathrm{B}_{42} \mathrm{~N}_{38} \mathrm{H}_{20}-\mathrm{M} 2$ (blue atoms represent nitrogen atoms and pink atoms represent boron atoms), (d) $\mathrm{Si}_{38} \mathrm{C}_{42} \mathrm{H}_{20}-\mathrm{M} 1$, (e) $\mathrm{Si}_{42} \mathrm{C}_{38} \mathrm{H}_{20}-\mathrm{M} 2$ (dark cyan atoms represent silicon atoms and grey atoms represent carbon atoms). 


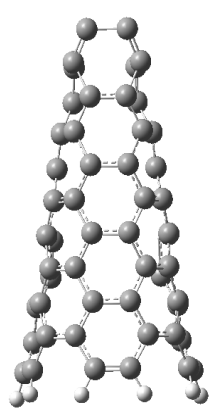

(a)

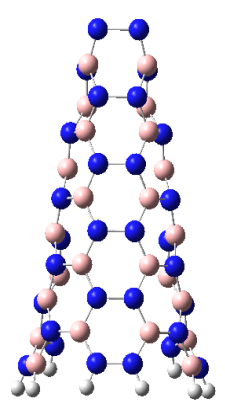

(b)

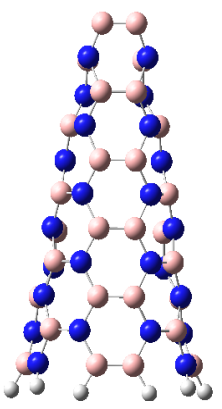

(c)

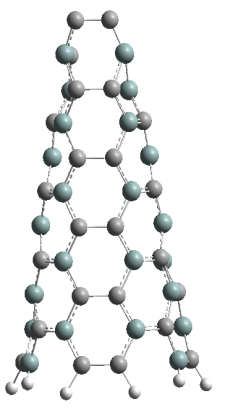

(d)

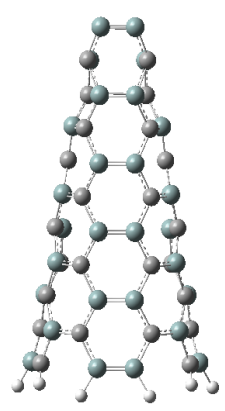

(e)

Figure 2. The fully optimized structures of nanocones with disclination angle $300^{\circ}$ (a) $\mathrm{C}_{75} \mathrm{H}_{9}$, (b) $\mathrm{B}_{34} \mathrm{~N}_{41} \mathrm{H}_{9}-\mathrm{M} 1$, (c) $\mathrm{B}_{41} \mathrm{~N}_{34} \mathrm{H}_{9}$-M2 (blue atoms represent nitrogen atoms and pink atoms represent boron atoms), (d) $\mathrm{Si}_{34} \mathrm{C}_{41} \mathrm{H}_{9}-\mathrm{M} 1$, (e) $\mathrm{Si}_{41} \mathrm{C}_{34} \mathrm{H}_{9}-\mathrm{M} 2$ (dark cyan atoms represent silicon atoms and grey atoms represent carbon atoms).

\section{Results and Discussion}

\subsection{Se-Doped Nanocones}

We investigate the optimized geometries of Se atom decorating the various types of nanocones, Se-CNCs, Se-BNNCs and Se-SiCNCs to study their stabilities and their abilities for hydrogen storage, see Figure 3. As shown in Figure 3, the structures of Se-doped nanocones with disclination angle $60^{\circ}$ are stable. Our calculated binding energies are found to be $-141.5 \mathrm{eV},-200.8 \mathrm{eV},-176.2 \mathrm{eV}$, $-246.0 \mathrm{eV}$ and $-213.0 \mathrm{eV}$ for Se- $\mathrm{C}_{80} \mathrm{H}_{20}$, Se- $\mathrm{B}_{38} \mathrm{~N}_{42} \mathrm{H}_{20}-\mathrm{M} 1$, Se $-\mathrm{B}_{42} \mathrm{~N}_{38} \mathrm{H}_{20}-\mathrm{M} 2$, Se- $\mathrm{Si}_{38} \mathrm{C}_{42} \mathrm{H}_{20}-\mathrm{M} 1$ and $\mathrm{Se}^{-} \mathrm{Si}_{42} \mathrm{C}_{38} \mathrm{H}_{20}-\mathrm{M} 2$, respectively.

Also, the binding energies for Se-doped nanocones with disclination angle $300^{\circ}$ are calculated and are found to be $-148.0 \mathrm{eV},-169.5 \mathrm{eV},-153.3 \mathrm{eV},-192.5$ $\mathrm{eV}$ and $-159.8 \mathrm{eV}$ for Se- $\mathrm{C}_{75} \mathrm{H}_{9}, \mathrm{Se}-\mathrm{B}_{34} \mathrm{~N}_{41} \mathrm{H}_{9}-\mathrm{M} 1$, Se- $\mathrm{B}_{41} \mathrm{~N}_{34} \mathrm{H}_{9}-\mathrm{M} 2$, Se- $\mathrm{Si}_{34} \mathrm{C}_{41} \mathrm{H}_{9}-\mathrm{M} 1$ and $\mathrm{Se}-\mathrm{Si}_{41} \mathrm{C}_{34} \mathrm{H}_{9}-\mathrm{M} 2$, respectively.

Once can report that the order of stability of nanocones as a function of binding energy is as the following: Se- $\mathrm{Si}_{38} \mathrm{C}_{42} \mathrm{H}_{20}-\mathrm{M} 1>\mathrm{Si}_{42} \mathrm{C}_{38} \mathrm{H}_{20}-\mathrm{M} 2>\mathrm{Se}-\mathrm{B}_{38} \mathrm{~N}_{42} \mathrm{H}_{20^{-}}$ $\mathrm{M} 1>\mathrm{Se}-\mathrm{B}_{42} \mathrm{~N}_{38} \mathrm{H}_{20}-\mathrm{M} 2>\mathrm{Se}-\mathrm{C}_{80} \mathrm{H}_{20}$ for Se-doped nanocones with disclination angle $60^{\circ}$ and $\mathrm{Se}_{-} \mathrm{Si}_{34} \mathrm{C}_{41} \mathrm{H}_{9}-\mathrm{M} 1>\mathrm{Se}^{-\mathrm{Si}_{41}} \mathrm{C}_{34} \mathrm{H}_{9}-\mathrm{M} 2>\mathrm{Se}-\mathrm{B}_{34} \mathrm{~N}_{41} \mathrm{H}_{9}-\mathrm{M} 1>\mathrm{Se}-\mathrm{B}_{41} \mathrm{~N}_{34} \mathrm{H}_{9}-$ $\mathrm{M} 2>\mathrm{Se}-\mathrm{C}_{75} \mathrm{H}_{9}$ for Se-doped nanocones with disclination angle $300^{\circ}$. This indicated that the Se-SiCNCs is the most stable structure among the three types of NCs. These results agree with the previous findings [4] [46].

\subsection{Adsorption Energy}

To identify a suitable nanocone for hydrogen storage, the hydrogen atoms adsorbed on pure and Se-doped nanocones. The fully optimized of hydrogen adsorption on the Se-doped nanocones with disclination angle $60^{\circ}$ for $\mathrm{Se}-\mathrm{C}_{80} \mathrm{H}_{20}$, Se- $\mathrm{B}_{38} \mathrm{~N}_{42} \mathrm{H}_{20}-\mathrm{M} 1$, Se- $\mathrm{B}_{42} \mathrm{~N}_{38} \mathrm{H}_{20}-\mathrm{M} 2$, Se-Si ${ }_{38} \mathrm{C}_{42} \mathrm{H}_{20}-\mathrm{M} 1$, and $\mathrm{Se}-\mathrm{Si}_{42} \mathrm{C}_{38} \mathrm{H}_{20}-\mathrm{M} 2$ configurations are shown in Figure 4. The hydrogen adsorption energy for pure nanocones with angle $60^{\circ}$ and $300^{\circ}$ ( $E_{\text {adsorption }}$ ) calculated according to the following expression: 


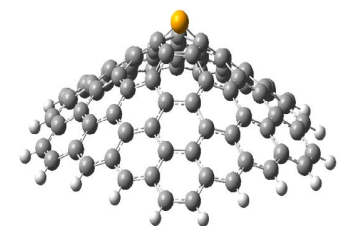

(a)

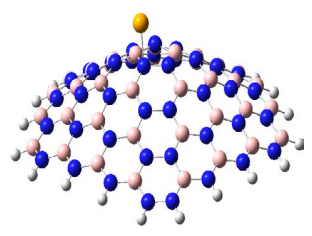

(b)

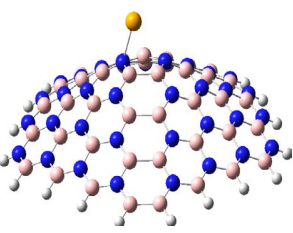

(c)

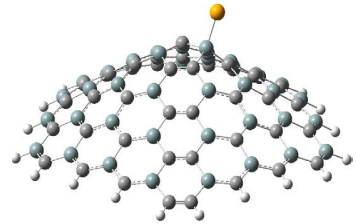

(d)

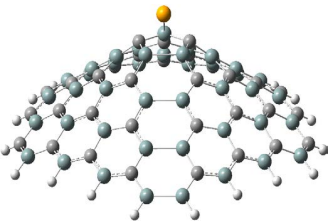

(e)

Figure 3. The fully optimized structures of Se-doped nanocones with disclination angle $60^{\circ}$ (a) Se- $\mathrm{C}_{80} \mathrm{H}_{20}$, (b) Se- $\mathrm{B}_{38} \mathrm{~N}_{42} \mathrm{H}_{20}-\mathrm{M} 1$, (c) Se- $\mathrm{B}_{42} \mathrm{~N}_{38} \mathrm{H}_{20}$-M2 (blue atoms represent nitrogen atoms, pink atoms represent boron atoms and yellow atom represent selenium atom), (d) $\mathrm{Se}_{-} \mathrm{Si}_{38} \mathrm{C}_{42} \mathrm{H}_{20}-\mathrm{M} 1$, (e) $\mathrm{Se}_{-} \mathrm{Si}_{42} \mathrm{C}_{38} \mathrm{H}_{20}-\mathrm{M} 2$ (dark cyan atoms represent silicon atoms and grey atoms represent carbon atoms).

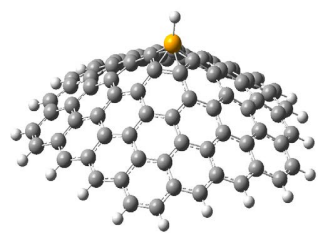

(a)

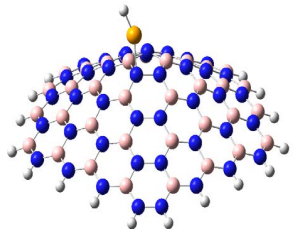

(b)

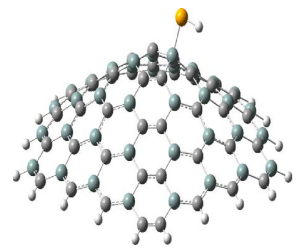

(d)

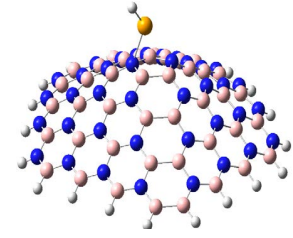

(c)

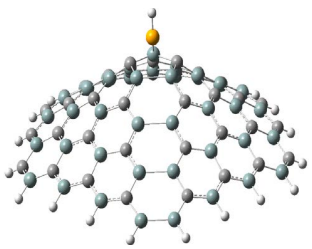

(e)

Figure 4. The fully optimized structures of hydrogen adsorption on the Se-doped nanocones with disclination angle $60^{\circ}$ (a) Se- $\mathrm{C}_{80} \mathrm{H}_{20}$, (b) $\mathrm{Se}-\mathrm{B}_{38} \mathrm{~N}_{42} \mathrm{H}_{20}-\mathrm{M} 1$, (c) Se- $\mathrm{B}_{42} \mathrm{~N}_{38} \mathrm{H}_{20}-\mathrm{M} 2$ (blue atoms represent nitrogen atoms, pink atoms represent boron atoms and yellow atom represent selenium atom), (d) $\mathrm{Se}_{-} \mathrm{Si}_{38} \mathrm{C}_{42} \mathrm{H}_{20}-\mathrm{M} 1$, (e) $\mathrm{Se}-\mathrm{Si}_{42} \mathrm{C}_{38} \mathrm{H}_{20}-\mathrm{M} 2$ (dark cyan atoms represent silicon atoms and grey atoms represent carbon atoms). 


$$
E_{\text {adsorption }}=E_{N C s-H}-E_{N C s}-E_{H}
$$

where $E_{N C S-H}$ is the energy of the optimized hydrogenated NCs structure, $E_{N C S}$ is the energy of an optimized pure NCs structure and $E_{H}$ is the energy of a hydrogen atom. At the same line, the hydrogen adsorption energy for doped Si-nanocones with angle $60^{\circ}$ and $300^{\circ}$ calculated as the difference between the energy of the optimized hydrogenated Se-NCs structure and the energy sum of the Se-NCs and the hydrogen atom. The adsorption energy for disclination angles $60^{\circ}$ and $300^{\circ}$ is shown in Table 1 . We measure the ability of pure and doped Se-CNCs, Se-BNNCs and Se-SiCNCs for hydrogen storage as a function of adsorption energy.

From Table 1, it's clear that the best adsorption energies are $-7.62 \mathrm{eV}$ and $-31.03 \mathrm{eV}$ for pure $\mathrm{Si}_{34} \mathrm{C}_{41} \mathrm{H}_{9}-\mathrm{M} 1$ and doped $\mathrm{Se}_{-} \mathrm{Si}_{34} \mathrm{C}_{41} \mathrm{H}_{9}-\mathrm{M} 1$ with disclination angle $300^{\circ}$. Also it's found that the hydrogen adsorption energies for all doped Se-CNCs, Se-BNNCs and Se-SiCNCs with disclination angles $60^{\circ}$ and $300^{\circ}$ are always more lower in energy than the adsorption energy for pure CNCs, BNNCs and SiCNCs with disclination angles $60^{\circ}$ and $300^{\circ}$. This finding indicates that the doping NCs with Selenium (Se) atom expected to increase the hydrogen storage capacity consistent with recent investigation of the hydrogen adsorption on graphene and graphene sheet doped with osmium and tungsten [52]. The best adsorption energy is found to be for SiCNCs with disclination angle $300^{\circ}$ because of the increased curvature effect and the physical-chemical properties of $\mathrm{SiC}$ such as excellent thermal conductivity, chemical inertness, high electron mobility, and biocompatibility, promises well for applications in microelectronics and optoelectronics, as well as nanocomposites [1] [4].

Table 1. The calculated adsorption energy of hydrogenated pure and doped Se-CNCs, Se-BNNCs and Se-SiCNCs with disclination angles $60^{\circ}$ and $300^{\circ}$. All energies are given by $\mathrm{eV}$.

\begin{tabular}{|c|c|c|c|}
\hline Angle $60^{\circ}$ & $E_{a d s}^{H}(\mathrm{eV})$ & Angle $300^{\circ}$ & $E_{\text {ads }}^{H}(\mathrm{eV})$ \\
\hline $\mathrm{C}_{80} \mathrm{H}_{20}$ & 0.93 & $\mathrm{C}_{75} \mathrm{H}_{9}$ & -1.93 \\
\hline $\mathrm{Se}-\mathrm{C}_{80} \mathrm{H}_{20}$ & -1.30 & $\mathrm{Se}-\mathrm{C}_{75} \mathrm{H}_{9}$ & 0.24 \\
\hline $\mathrm{B}_{38} \mathrm{~N}_{42} \mathrm{H}_{20}-\mathrm{M} 1$ & 0.91 & $\mathrm{~B}_{34} \mathrm{~N}_{41} \mathrm{H} 9-\mathrm{M} 1$ & -0.91 \\
\hline Se- ${ }_{38} \mathrm{~N}_{42} \mathrm{H}_{20}-\mathrm{M} 1$ & -2.43 & Se- $\mathrm{B}_{34} \mathrm{~N}_{41} \mathrm{H}_{9}-\mathrm{M} 1$ & -7.38 \\
\hline $\mathrm{B}_{42} \mathrm{~N}_{38} \mathrm{H}_{20}-\mathrm{M} 2$ & 0.69 & $\mathrm{~B}_{41} \mathrm{~N}_{34} \mathrm{H}_{9}-\mathrm{M} 2$ & -0.49 \\
\hline Se- $\mathrm{B}_{42} \mathrm{~N}_{38} \mathrm{H}_{20}-\mathrm{M} 2$ & -0.01 & $\mathrm{Se}-\mathrm{B}_{41} \mathrm{~N}_{34} \mathrm{H}_{9}-\mathrm{M} 2$ & -16.38 \\
\hline $\mathrm{Si}_{38} \mathrm{C}_{42} \mathrm{H}_{20}-\mathrm{M} 1$ & 1.64 & $\mathrm{Si}_{34} \mathrm{C}_{41} \mathrm{H}_{9}-\mathrm{M} 1$ & -7.62 \\
\hline $\mathrm{Se}-\mathrm{Si}_{38} \mathrm{C}_{42} \mathrm{H}_{20}-\mathrm{M} 1$ & -4.63 & $\mathrm{Se}-\mathrm{Si}_{34} \mathrm{C}_{41} \mathrm{H}_{9}-\mathrm{M} 1$ & -31.03 \\
\hline $\mathrm{Si}_{42} \mathrm{C}_{38} \mathrm{H}_{20}-\mathrm{M} 2$ & 0.75 & $\mathrm{Si}_{41} \mathrm{C}_{34} \mathrm{H}_{9}-\mathrm{M} 2$ & -3.93 \\
\hline $\mathrm{Se}-\mathrm{Si}_{42} \mathrm{C}_{38} \mathrm{H}_{20}-\mathrm{M} 2$ & -3.53 & $\mathrm{Se}-\mathrm{Si}_{41} \mathrm{C}_{34} \mathrm{H}_{9}-\mathrm{M} 2$ & -23.68 \\
\hline
\end{tabular}




\subsection{Surface Reactivity and Energy Gaps}

The dipole moments used as indicator for the surface reactivity where the high values of the dipole moments indicate the high surface reactivity [42] [43]. Therefore, the dipole moments for pure and doped Se- $\mathrm{C}_{80} \mathrm{H}_{20}$, Se- $\mathrm{B}_{38} \mathrm{~N}_{42} \mathrm{H}_{20}-\mathrm{M} 1$, Se- $\mathrm{B}_{42} \mathrm{~N}_{38} \mathrm{H}_{20}-\mathrm{M} 2$, Se-Si ${ }_{38} \mathrm{C}_{42} \mathrm{H}_{20}-\mathrm{M} 1$, and $\mathrm{Se}_{-} \mathrm{Si}_{42} \mathrm{C}_{38} \mathrm{H}_{20}-\mathrm{M} 2$ with disclination angle $60^{\circ}$ as well as for pure and doped Se- $\mathrm{C}_{75} \mathrm{H}_{9}$, Se- $\mathrm{B}_{34} \mathrm{~N}_{41} \mathrm{H}_{9}-\mathrm{M} 1$, Se- $\mathrm{B}_{41} \mathrm{~N}_{34} \mathrm{H}_{9}-\mathrm{M} 2$, $\mathrm{Se}-\mathrm{Si}_{34} \mathrm{C}_{41} \mathrm{H}_{9}-\mathrm{M} 1$ and $\mathrm{Se}-\mathrm{Si}_{41} \mathrm{C}_{34} \mathrm{H}_{9}-\mathrm{M} 2$ with disclination angle $300^{\circ}$ are calculated. Both of the surface reactivity and the energy gaps are considered to be the most important properties which can provide with the fundamental information required for designing the next generation of nanocones devices. Hence, the surface reactivity and energy gaps for disclination angles $60^{\circ}$ and $300^{\circ}$ investigated for pure and Se-doped NCs and listed in Table 2.

From Table 2, the surface reactivity of pure and doped Se-CNCs, Se-SiCNCs and Se-BNNCs structures is increased by increasing the disclination angles from $60^{\circ}$ to $300^{\circ}$. The smallest and largest surface reactivity for CNCs found to be 1.29 Debye and 19.63 Debye for $\mathrm{Se}-\mathrm{C}_{80} \mathrm{H}_{20}$ and $\mathrm{C}_{75} \mathrm{H}_{9}$ CNCs with disclination angles $60^{\circ}$ and $300^{\circ}$, respectively. As well as for BNNCs, their surfaces reactivity are increased by increasing the disclination angles, the smallest and largest surfaces reactivity are found to be 8.51 Debye and 15.22 Debye for Se- $\mathrm{B}_{42} \mathrm{~N}_{38} \mathrm{H}_{20}-\mathrm{M} 2$ and $\mathrm{B}_{34} \mathrm{~N}_{41} \mathrm{H} 9-\mathrm{M} 1$ with disclination angles $60^{\circ}$ and $300^{\circ}$,respectively. For the SiCNCs, the surfaces reactivity are also increased by increasing the disclination angles where the smallest and largest surfaces reactivity are found to be 6.81 Debye and 39.73 Debye for $\mathrm{Si}_{38} \mathrm{C}_{42} \mathrm{H}_{20}-\mathrm{M} 1$ and $\mathrm{Se}^{-} \mathrm{Si}_{34} \mathrm{C}_{41} \mathrm{H}_{9}-\mathrm{M} 1$ with disclination angles $60^{\circ}$ and $300^{\circ}$, respectively. It's noticed that the surface reactivity increased by increasing the disclination angle because by increasing the disclination angle, the strain on the cone is increased, resulting in an increase in the surface reactivity. Also, it is clear the effect of Se atom in increasing the electron density around its position resulting in an increase of hydrogen adsorption and hydrogen storage, see Figure 5.

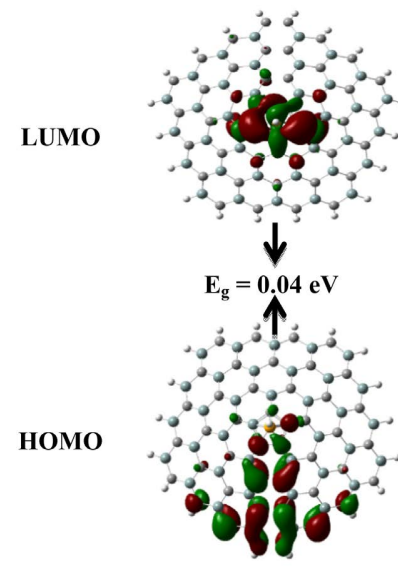

(a)

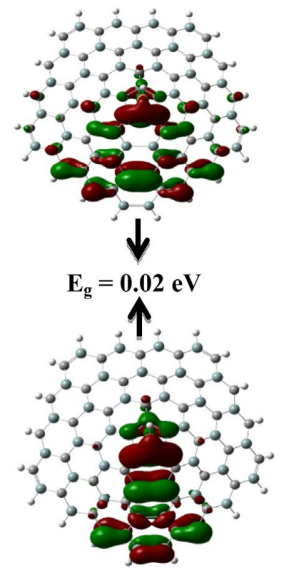

(b)

Figure 5. The molecular orbital of LUMOs and HOMOs for hydrogenated doped

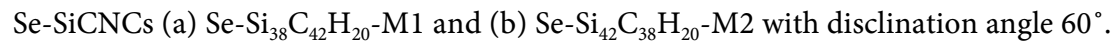


Table 2. The dipole moments and energy gaps of hydrogenated pure and doped Se-CNCs, Se-BNNCs and Se-SiCNCs with disclination angles $60^{\circ}$ and $300^{\circ}$. The dipole moment is given by Debye and the energy gap is given by $\mathrm{eV}$.

\begin{tabular}{|c|c|c|c|c|c|}
\hline $\begin{array}{c}\text { Angle } \\
60^{\circ}\end{array}$ & $\begin{array}{l}\text { Dipole } \\
\text { Moment } \\
\text { (Debye) }\end{array}$ & $\begin{array}{c}\text { E.g } \\
(\mathrm{eV})\end{array}$ & $\begin{array}{c}\text { Angle } \\
300^{\circ}\end{array}$ & $\begin{array}{c}\text { Dipole } \\
\text { Moment } \\
\text { (Debye) }\end{array}$ & $\begin{array}{l}\text { E.g } \\
(\mathrm{eV})\end{array}$ \\
\hline $\mathrm{C}_{80} \mathrm{H}_{20}$ & 6.80 & 0.06 & $\mathrm{C}_{75} \mathrm{H}_{9}$ & 19.63 & 0.03 \\
\hline $\mathrm{Se}-\mathrm{C}_{80} \mathrm{H}_{20}$ & 1.29 & 0.03 & $\mathrm{Se}-\mathrm{C}_{75} \mathrm{H}_{9}$ & 14.02 & 0.01 \\
\hline $\mathrm{B}_{38} \mathrm{~N}_{42} \mathrm{H}_{20}-\mathrm{M} 1$ & 9.23 & 0.01 & $\mathrm{~B}_{34} \mathrm{~N}_{41} \mathrm{H} 9-\mathrm{M} 1$ & 15.22 & 0.02 \\
\hline $\mathrm{Se}-\mathrm{B}_{38} \mathrm{~N}_{42} \mathrm{H}_{20}-\mathrm{M} 1$ & 6.93 & 0.05 & $\mathrm{Se}-\mathrm{B}_{34} \mathrm{~N}_{41} \mathrm{H}_{9}-\mathrm{M} 1$ & 9.84 & 0.06 \\
\hline $\mathrm{B}_{42} \mathrm{~N}_{38} \mathrm{H}_{20}-\mathrm{M} 2$ & 9.10 & 0.01 & $\mathrm{~B}_{41} \mathrm{~N}_{34} \mathrm{H}_{9}-\mathrm{M} 2$ & 8.95 & 0.03 \\
\hline $\mathrm{Se}-\mathrm{B}_{42} \mathrm{~N}_{38} \mathrm{H}_{20}-\mathrm{M} 2$ & 8.51 & 0.04 & $\mathrm{Se}-\mathrm{B}_{41} \mathrm{~N}_{34} \mathrm{H}_{9}-\mathrm{M} 2$ & 9.52 & 0.06 \\
\hline $\mathrm{Si}_{38} \mathrm{C}_{42} \mathrm{H}_{20}-\mathrm{M} 1$ & 6.81 & 0.01 & $\mathrm{Si}_{34} \mathrm{C}_{41} \mathrm{H}_{9}-\mathrm{M} 1$ & 17.91 & 0.01 \\
\hline $\mathrm{Se}-\mathrm{Si}_{38} \mathrm{C}_{42} \mathrm{H}_{20}-\mathrm{M} 1$ & 8.29 & 0.04 & $\mathrm{Se}-\mathrm{Si}_{34} \mathrm{C}_{41} \mathrm{H}_{9}-\mathrm{M} 1$ & 39.73 & 0.02 \\
\hline $\mathrm{Si}_{42} \mathrm{C}_{38} \mathrm{H}_{20}-\mathrm{M} 2$ & 9.89 & 0.01 & $\mathrm{Si}_{41} \mathrm{C}_{34} \mathrm{H}_{9}-\mathrm{M} 2$ & 21.94 & 0.06 \\
\hline $\mathrm{Se}-\mathrm{Si}_{42} \mathrm{C}_{38} \mathrm{H}_{20}-\mathrm{M} 2$ & 11.19 & 0.02 & $\mathrm{Se}-\mathrm{Si}_{41} \mathrm{C}_{34} \mathrm{H}_{9}-\mathrm{M} 2$ & 29.73 & 0.02 \\
\hline
\end{tabular}

Therefore, in our work, we found that by increasing the disclination angle as well as by doping nanocones with Se atom the hydrogen storage capacity improved especially for SiCNCs. These results go well with previous work [1] [4] [23] [46].

\section{Conclusion}

We used the DFT to study the hydrogen adsorption on pure and doped Se-CNCs, Se-BNNCs and Se-SiCNCs. The obtained results show that by increasing the disclination angle, the adsorption energy of hydrogen is enhanced. In addition, doping nanocones with Se-atom cause an increase in surface reactivity and hydrogen storage. The doped Se-SiCNC was found to be the best nanocone for hydrogen storage. The adsorption energy and the surface reactivity were obtained to be $-31.03 \mathrm{eV}$ and 39.73 Debye for Se-Si ${ }_{34} \mathrm{C}_{41} \mathrm{H}_{9}-\mathrm{M} 1$ with disclination angle $300^{\circ}$, respectively. Finally, one can conclude that the doped Se-SiCNCs are expected to be the best candidate nanocones for highly efficient hydrogen storage capacity.

\section{Conflicts of Interest}

The authors declare no conflicts of interest regarding the publication of this paper.

\section{References}

[1] Al-Khateeb, M.A. and El-Barbary, A.A. (2020) Hydrogen Adsorption Mechanism of SiC Nanocones. Graphene, 9, 1-12. https://doi.org/10.4236/graphene.2020.91001

[2] El-Barbary, A.A., Kamel, M.A., Eid, K.M., Taha, H.O., Mohamed, R.A. and 
Al-Khateeb, M.A. (2015) The Surface Reactivity of Pure and Monohydrogenated Nanocones Formed from Graphene Sheets. Graphene, 45, 75-83. https://doi.org/10.4236/graphene.2015.44008

[3] Iijima, S. (1991) Helical Microtubules of Graphitic Carbon. Nature, 354, 56-58. https://doi.org/10.1038/354056a0

[4] El-Barbary, A.A. (2019) Hydrogen Storage on Cross Stacking Nanocones. International Journal of Hydrogen Energy, 44, Article ID: 20099. https://doi.org/10.1016/j.ijhydene.2019.05.043

[5] Sattler, K. (1995) Scanning Tunneling Microscopy of Carbon Nanotubes and Nanocones. Carbon, 33, 915-920. https://doi.org/10.1016/0008-6223(95)00020-E

[6] EL-Barbary, A.A. (2018) Vacancy Cluster in Graphite: Migration Mechanism and Aggregation. AIP Conference Proceedings, 1976, Article ID: 020006. https://doi.org/10.1063/1.5042373

[7] Ewels, C.P., Telling, R.H., El-Barbary, A.A. and Heggie, M.I. (2003) Metastable Frenkel Pair Defect in Graphite: Source of Winger Energy. Physical Review Letters, 91, Article ID: 25505. https://doi.org/10.1103/PhysRevLett.91.025505

[8] EL-Barbary, A.A. (2017) New Insights into Canted Spiro Carbon Interstitial in Graphite. Applied Surface Science, 426, 238-243. https://doi.org/10.1016/j.apsusc.2017.07.196

[9] Alfieri, G. and Kimoto, T. (2009) The Structural and Electronic Properties of Chiral SiC Nanotubes: A Hybrid Density Functional Study. Nanotechnology, 20, Article ID: 285703. https://doi.org/10.1088/0957-4484/20/28/285703

[10] EL-Barbary, A.A. (2016) Hydrogenated Fullerenes in Space: FT-IR Spectra Analysis. AIP Conference Proceedings, 1742, Article ID: 030005. https://doi.org/10.1063/1.4953126

[11] Gali, A. (2006) Ab Initio Study of Nitrogen and Boron Substitutional Impurities in Single-Wall SiC Nanotubes. Physical Review B, 73, Article ID: 245415. https://doi.org/10.1103/PhysRevB.73.245415

[12] EL-Barbary, A.A. (2016) Hydrogenated Fullerenes Dimer, Peanut and Capsule: An Atomic Comparison. Applied Surface Science, 369, 50-57.

https://doi.org/10.1016/j.apsusc.2016.02.033

[13] Nikitin, A., Li, X.L., Zhang, Z.Y., Ogasawara, H., Dai, H.J. and Nilsson, A. (2008) Hydrogen Storage in Carbon Nanotubes through the Formation of Stable C-H Bonds. Nano Letters, 8, 162-167. https://doi.org/10.1021/nl072325k

[14] EL-Barbary, A.A. (2016) Potential Energy of $\mathrm{H}_{2}$ inside the C116 Fullerene Dimerization: An Atomic Analysis. Journal of Molecular Structure, 1112, 9-13. https://doi.org/10.1016/j.molstruc.2016.02.007

[15] Zhu, J., Yu, Z., Burkhard, G.F., Hsu, C.M., Connor, S.T., Xu, Y., Wang, Q., McGehee, M., Fan, S. and Cui, Y. (2009) Optical Absorption Enhancement in Amorphous Silicon Nanowire and Nanocone Arrays. Nano Letters, 9, 279-282. https://doi.org/10.1021/nl802886y

[16] EL-Barbary, A.A. (2016) Hydrogenation Mechanism of Small Fullerene Cages. International Journal of Hydrogen Energy, 41, 375-383. https://doi.org/10.1016/j.ijhydene.2015.10.102

[17] Yang, F.H., Lachawiec, A.J. and Yang, R.T. (2006) Hydrogen Sorption on Palladium-Doped Sepiolite-Derived Carbon Nanofibers. The Journal of Physical Chemistry $B, 110,6236-6244$. https://doi.org/10.1021/jp056461u

[18] El-Barbary, A.A., Kamel, M.A., Eid, K.M., Taha, H.O. and Hassan, M.M. (2015) 
Mono-Vacancy and B-Doped Defects in Carbon Heterojunction Nanodevices. Graphene, 4, 84-90. https://doi.org/10.4236/graphene.2015.44009

[19] Zetterling, C.M. (2002) Process Technology for Silicon Carbide Devices. IET, London. https://doi.org/10.1049/PBEP002E

[20] El-Barbary, A.A., Eid, K.M., Kamel, M.A., Taha, H.O. and Ismail, G.H. (2015) Adsorption of $\mathrm{CO}, \mathrm{CO}_{2}, \mathrm{NO}$ and $\mathrm{NO}_{2}$ on Boron Nitride Nanotubes: DFT Study. Journal of Surface Engineered Materials and Advanced Technology, 5, 154-161. https://doi.org/10.4236/jsemat.2015.53017

[21] Wu, J.J. and Guo, G.Y. (2007) Optical Properties of SiC Nanotubes: An Ab Initio Study. Physical Review B, 76, Article ID: 035343.

https://doi.org/10.1103/PhysRevB.76.035343

[22] El-Barbary, A.A., Eid, K.M., Kamel, M.A., Taha, H.O. and Ismail, G.H. (2015) Adsorption of $\mathrm{CO}, \mathrm{CO}_{2}, \mathrm{NO}$ and $\mathrm{NO}_{2}$ on Carbon Boron Nitride Hetero Junction: DFT Study. Journal of Surface Engineered Materials and Advanced Technology, 5, 169-176. https://doi.org/10.4236/jsemat.2015.54019

[23] Harris, G.L. (1995) Properties of Silicon Carbide. INSPEC, the Institution of Electrical Engineers, London.

[24] El-Barbary, A.A., Eid, K.M., Kamel, M.A., Taha, H.O. and Ismail, G.H. (2014) Effect of Tubular Chiralities and Diameters of Single Carbon Nanotubes on Gas Sensing Behavior: A DFT Analysis. Journal of Surface Engineered Materials and Advanced Technology, 4, 66-74. https://doi.org/10.4236/jsemat.2014.42010

[25] Liu, C. and Cheng, H.M. (2005) Carbon Nanotubes for Clean Energy Applications. Journal of Physics D: Applied Physics, 38, 231-252. https://doi.org/10.1088/0022-3727/38/14/R01

[26] El-Barbary, A.A., Ismail, G.H. and Babaier, A. (2013) Theoretical Study of Adsorbing $\mathrm{CO}, \mathrm{CO}_{2}, \mathrm{NO}$ and $\mathrm{NO}_{2}$ on Carbon Nanotubes. Journal of Surface Engineered Materials and Advanced Technology, 3, 287-294.

https://doi.org/10.4236/jsemat.2013.34039

[27] El-Barbary, A.A., Telling, R.H., Ewels, C.P. and Heggie, M.I. (2003) Structural and Energetics of the Vacancy in Graphite. Physical Review B, 68, Article ID: 144107. https://doi.org/10.1103/PhysRevB.68.144107

[28] Telling, R.H., Ewels, C.P., El-Barbary, A.A. and Heggie, M.I. (2003) Wigner Defects Bridge the Graphite Gap. Nature Materials, 2, 333-337.

https://doi.org/10.1038/nmat876

[29] Matsunami, H. (2004) Technological Breakthroughs in Growth Control of Silicon Carbide for High Power Electronic Devices. Japanese Journal of Applied Physics, 43, 6835. https://doi.org/10.1143/JJAP.43.6835

[30] EL-Barbary, A.A. (2015) The Surface Reactivity and Electronic Properties of Small Hydrogenation Fullerene Cages. Journal of Surface Engineered Materials and Advanced Technology, 5, 162-168. https://doi.org/10.4236/jsemat.2015.53018

[31] Garberg, S.N., Naess, G., Helgesen, K.D., Knudsen, G., Kopstad, A. and Elgsaeter, A. (2008) Transmission Electron Microscopeand Electron Diraction Study of Carbon Nanodisks. Carbon, 46, 1535-1543. https://doi.org/10.1016/j.carbon.2008.06.044

[32] EL-Barbary, A.A. (2015) $1 \mathrm{H}$ and 13C NMR Chemical Shift Investigations of Hydrogenated Small Fullerene Cages $\mathrm{Cn}, \mathrm{CnH}, \mathrm{CnHn}$ and $\mathrm{CnHn}+1: \mathrm{n}=20,40,58,60$. Journal of Molecular Structure, 1097, 76-86. https://doi.org/10.1016/j.molstruc.2015.05.015

[33] Mavrandonakis, A., Froudakis, G.E., Andriotis, A. and Menon, M. (2006) Silicon 
Carbide Nanotube Tips: Promising Materials for Atomic Force Microscopy and/or Scanning Tunneling Microscopy. Physical Review Letters, 89, Article ID: 123126. https://doi.org/10.1063/1.2221418

[34] Hindi, A.A. and EL-Barbary, A.A. (2015) Hydrogen Storage on Halogenated C40 Cage: An Intermediate between Physisorption and Chemisorptions. Journal of Molecular Structure, 1080, 169-175. https://doi.org/10.1016/j.molstruc.2014.09.034

[35] El-Barbary, A.A., Lebda, H.I. and Kamel, M.A. (2009) The High Conductivity of Defect Fullerene C40 Cage. Computational Materials Science, 46, 128-132. https://doi.org/10.1016/j.commatsci.2009.02.034

[36] Berry, G.D. and Aceves, S.M. (1998) Onboard Storage Alternatives for Hydrogen Vehicles. Energy Fuels, 12, 49-55. https://doi.org/10.1021/ef9700947

[37] Chen, P., Wu, X., Lin, J. and Tan, K.L. (1999) High $\mathrm{H}_{2}$ Uptake by Alkali-Doped Carbon Nano Tubes under Ambient Pressure and Moderate Temperatures. Science, 285, 91-93. https://doi.org/10.1126/science.285.5424.91

[38] Strobel, R., Garche, J., Moseley, P.T., Jorissen, L. and Wolf, G. (2006) Hydrogen Storage by Carbon Materials. Journal of Power Sources, 159, 781-801.

https://doi.org/10.1016/j.jpowsour.2006.03.047

[39] Baughman, R.H., Zakhidov, A.A. and De Heer, W.A. (2002) Carbon NanotubesThe Route toward Applications. Science, 297, 787-792.

https://doi.org/10.1126/science.1060928

[40] Yang, F.H. and Yang, R.T. (2002) Adsorption Behaviors of HiPco Single-Walled Carbon Nanotube Aggregates for Alcohol Vapors. The Journal of Physical Chemistry, 106, 8994-8999. https://doi.org/10.1021/jp025767n

[41] Zhao, Y., Kim, Y.H., Dillon, A.C., Heben, M.J. and Zhang, S.B. (2005) Ab Initio Design of Ca-Decorated Organic Frameworks for High Capacity Molecular Hydrogen Storage with Enhanced Binding. Physical Review Letters, 95, Article ID: 033109.

[42] El-Nahass, M.M., Kamel, M.A., El-Barbary, A.A., El-Mansy, M.A.M. and Ibrahim, M. (2013) On the Spectroscopic Analyses of Thioindigo Dye. Spectrochimica Acta Part A: Molecular and Biomolecular Spectroscopy, 113, 332-336. https://doi.org/10.1016/j.saa.2013.05.014

[43] Kotz, J.C., Treichel, P. and Weaver, G.C. (2006) Chemistry and Chemical Reactivity. Thomson Brooks Cole, Pacific Grove.

[44] Shalabi, A.S., Eid, Kh.M., Kamel, M.A. and El-Barbary, A.A. (1998) Comparative Study of Errors in $\mathrm{HeH}^{-}$Interaction Energy Calculations. International Journal of Quantum Chemistry, 68, 329. https://doi.org/10.1002/(SICI)1097-461X(1998)68:5<329::AID-QUA4>3.0.CO;2-X

[45] Shalabi, A.S., Eid, Kh.M., Kamel, M.A. and El-Barbary, A.A. (1998) Potential Energy Curves of $\mathrm{H}$ and $\mathrm{H}^{-}$Interactions with He. Physics Letters A, 239, 87-93. https://doi.org/10.1016/S0375-9601(97)00938-9

[46] Savini, G., El Barbary, A.A., Heggie, M.I. and Öberg, S. (2007) Partial Dislocations under Forward Bias in SiO. Materials Science Forum, 556, 279-282. https://doi.org/10.4028/www.scientific.net/MSF.556-557.279

[47] Suarez-Martinez, El Barbary, A.A., Savini, G. and Heggie, M.I. (2007) First-Principles Simulations of Boron Diffusion in Graphité. Physical Review Letters, 98, Article ID: 015501. https://doi.org/10.1103/PhysRevLett.98.015501

[48] Becke, A.D. (1993) Density-Functional Thermochemistry. III. The Role of Exact Exchange. Chemical Physics, 98, 5648. https://doi.org/10.1063/1.464913

[49] Vosko, S.H., Wilk, L., Nusair, M. and Can, J. (1980) Influence of an Improved Lo- 
cal-Spin-Density Correlation-Energy Functional on the Cohesive Energy of Alkali Metals. Physical Review B, 22, 3812-3815.

https://doi.org/10.1103/PhysRevB.22.3812

[50] Frisch, M.J., Trucks, G.W., Schlegel, H.B., Scuseria, G.E., Robb, M.A., Cheeseman, J.R., Zakrzewski, V.G., Montgomery, J.A., Stratmann, R.E., Burant, J.C., Dapprich, S., Millam, J.M., Daniels, A.D., Kudin, K.N., Strain, M.C., Farkas, O., Tomasi, J., Barone, V., Cossi, M., Cammi, R., Mennucci, B., Pomelli, C., Adamo, C., Clifford, S., Ochterski, J., Petersson, G.A., Ayala, P.Y., Cui, Q., Morokuma, K., Malick, D.K., Rabuck, A.D., Raghavachari, K., Foresman, J.B., Cioslowski, J., Ortiz, J.V., Stefanov, B.B., Liu, G., Liashenko, A., Piskorz, P., Komaromi, I., Gomperts, R., Martin, R.L., Fox, D.J., Keith, T., Al-Lamham, M., Peng, C.Y., Nanayakkara, A., Gonzalez, C., Challacombe, M., Gill, P.M.W., Johnson, B.G., Chen, W., Wong, M.W., Andres, J.L., Head-Gordon, M., Replogle, E.S. and Pople, J.A. (2004) Gaussian 2004. Gaussian Inc., Wallingford.

[51] Frisch, A., Dennington, R.D., Keith, T.A., Millam, J., Nielsen, A.B., Holder, A.J. and Hiscocks, J. (2003) Gauss View Manual Version 4. Gaussian Inc., Wallingford.

[52] Alshareef, B. (2020) DFT Investigation of the Hydrogen Adsorption on Graphene and Graphene Sheet Doped with Osmium and Tungsten. Open Journal of Physical Chemistry, 10, 197-204. https://doi.org/10.4236/ojpc.2020.104012 